\title{
Determination of Sexual and Reproductive Health Stigmatization Levels of Young Women
}

\author{
(1) Metin Yıldız, (1) Mehmet Salih Yıldırım, ${ }^{2}$ (D) Güray Okyar ${ }^{1}$ \\ 'Department of Nursing, Ağrı İbrahim Çeçen Unıversity, Ağrı, Turkey \\ ${ }^{2}$ Department of Podology, Iğdır Unıversity, lğdır, Turkey
}

\section{ABSTRACT}

Objectives: This research was carried out to investigate the sexual and reproductive health stigmatization levels of young women.

Methods: This cross-sectional study was conducted between 18-24 years old women registered in the Family Health Centers located in Igdir city center between March and April 2020.

Results: In this study, the median value of the Sexual and Reproductive Health Stamping Scale was 8.0 [6.0] in young women. The median value of "Accepted stigma", "Internalized stigma", "Stigma based attitudes", which are sub-dimensions of the the Sexual and Reproductive Health Stamping Scale in young women, were found as 3.0 [3.0], 2.0 [4.0], 3.0 [3.0], respectively. A positive statistically significant relationship was found between the Sexual and Reproductive Health Stigma Scale subscales Attitudes Based on Stigma and age in young women $(r=0.171, p=0.004)$.

Please cite this article as: Yıldız M, Yıldırım MS, Okyar G. Determination of Sexual and Reproductive Health Stigmatization Levels of Young Women. Anatol J Family Med 2020;3(3):254-259.

Address for correspondence: MscN, RN. Metin Yıldız. Department of Nursing, Ağrı İbrahim Çeçen Unıversity, Ağrı, Turkey

Phone: +90 5424693795

E-mail: yildizz.metin@gmail.com

Received Date: 11.05 .2020

Accepted Date: 16.06.2020

Published online: 12.11 .2020

(C) Copyright 2020 by Anatolian Journal of Family Medicine -

Available online at www.anatoljfm.org

OPEN ACCESS

Conclusion: The results suggest that the level of stigmatization may vary according to the level of education and income, and it is recommended to provide training on stigmatizing sexual and reproductive health for this group.

Keywords: Health, sexuality, stereotyped behavior, women

\section{INTRODUCTION}

The adolescent period that starts with puberty and continues until adulthood is a period when biological and psychological changes occur. ${ }^{[1]}$ Young individuals are responsible for their own health needs and accurate information about their health, especially reproductive health,to receive. ${ }^{[2-4]}$ Young people living in developing countries do not have sufficient information on sexual and reproductive health issues. ${ }^{[2-4]}$ Studies in our country also show that young people do not have sufficient information about issues involving sexual and reproductive health. ${ }^{[2-4]}$ Reproductive health refers to the right of people to be responsible, satisfying and safe in their sexual lives and to decide and choose when and how often they should use their reproductive capacity. ${ }^{[5]}$ Many young individuals in the adolescent period become sexually active. ${ }^{[6]}$ However, individuals in this period may not think about what the consequences of their sexual behavior will bring. ${ }^{[7]}$ As a result of unconscious risky sexual behaviors, some sexually transmitted diseases (STIs) are exposed, and these young individuals may face stigma due to reproductive health problems. Charlton states that structural stigmatization is a potential risk factor for negative reproductive health among female 
adolescents in the sexual minority. ${ }^{[8]}$ Stigma is defined as a highly reputable, humiliating situation made by other people towards individuals. ${ }^{[9]}$ The most common stigma about health includes mental diseases, obesity, HIV/ AIDS, disability and bisexual and homosexual types. ${ }^{[10-12]}$ Prejudices and beliefs form the basis of stigmatization. ${ }^{[13]}$ Social, cultural and religious norms define the situations that may occur as a result of adolescents' sexual behavior (e.g., pregnancy, premature birth, abortion and STI) as immoral and cause stigmatization of the individual. [13-15] Stigma also prevents the young person from receiving reproductive health services and benefiting from counseling services, HIV testing, health care, treatment and access to preventive services. ${ }^{[16]}$ In addition, stigma may lead young people to anxiety, depression, substance abuse and suicide. ${ }^{[17]}$

This research aims to stigmatize the sexual and reproductive health of women going through a sensitive period and aims to add new information to the literature due to the limited number of studies on this subject.

\section{METHOD}

This cross-sectional study was conducted between 18-24 years old women registered in the Family Health Centers located in the city center of Igdir between March and April 2020. The population of the study comprised of 137.613 individuals registered in the Family Health Centers in Igdir province, $12.2 \%$ of whom were women aged $18-24$ years. The sample of this study was $1.6 \%$ women in this age group who agreed to participate in this study.

In the collection of the research data, the Introductory Information Form and the Sexual and Reproductive Health Stigma Scale (SRHSS) in young women were used. After the purpose of this research was announced and verbal permission was obtained from the individuals who voluntarily agreed to participate in this research, the data were applied to individuals online using social media with the Google form prepared by the researchers.

\section{Data Collection Tools}

Introductory Information Form: It consists of questions that were prepared by researchers and contain the introductory features of individuals.

SRHSS Form: SRHSS was developed by Hall et al. to investigate the stigma of sexual and reproductive health in women aged 15-24 years in 2017. ${ }^{[18]}$ The original scale consists of three sub-dimensions and 20 items: Accepted stamping, Internalized Stamping, and Attitudes Based on Stamping. The lowest score that can be obtained from the total of the scale is 0 and, the highest score is 20. Each item of the scale is rated as $0=$ disagree, $0=$ neutral, $1=$ agree. The increase in the score obtained from the scale indicates that the stigma has increased. Bayrakceken performed the Turkish validity and reliability of the scale. Cronbach's alpha value was $0.74 .^{[19]}$

The data obtained in this study was analysed on the computer using the SPSS statistical software. Frequency, frequency, percentage, mean, standard deviation, median and interquartile range $[\mathrm{IQR}]$ were used as descriptive statistical methods. Kolmogorov-Smirnov test was used to test normality distribution with analytical tests. Mann-Whitney $U$ test was used for binary groups and, Kruskal-Wallis test was used for groups more than two. Spearman correlation test was used to investigate whether there was a linear relationship between the two numerical measurements. A p-value less than 0.05 was considered significant.

\section{RESULTS}

A total of 282 women were included in the study and the mean age was $21.2 \pm 1.7$ years. Sociodemographic characteristics of the individuals are summarized in Table 1.

The SRHSS score in young women was statistically significantly higher in primary school graduates, individuals with lower income and without health insurance $(p=0.036, p=0.047, p=0.033$, respectively). SRHSS scores according to sociodemographic characteristics are summarized in Table 2.

According to the results obtained from this study, the median value of the total SRHSS score was 8.0 [6.0] in young women. SRHSS total and sub-dimension scores in young women are summarized in Table 3.

When the relationship between SRHSS subscale scores and age was evaluated, the results showed that there was a positive relationship between "Attitudes Based on Stigma", one of the SRHSS subscales, and age in young women $(r=0.171, p=0.004)$. Relationship between SRHSS scale total and sub-dimension scores with age in young women are summarized Table 4.

\section{DISCUSSION}

For STIs, physical pain is mild and decreases fairly quickly when treatment begins. However, when it comes to the emotional pain caused by the stigma associated with STIs, the probability of living with STIs for the rest of a person's life may be more destructive. ${ }^{[20]}$ Nurses should be able to talk to patients about sexual and reproductive health issues, which are considered confidential and not easily communicated among people, and to identify individuals at risk early. They should provide training and consultancy services to these risky groups. ${ }^{[21]}$ 


\begin{tabular}{|c|c|}
\hline & Mean \pm SD \\
\hline \multirow[t]{2}{*}{ Age (years) } & $21.2 \pm 1.7$ \\
\hline & n (\%) \\
\hline \multicolumn{2}{|l|}{ Nationality } \\
\hline Turkey & 89 (31.6) \\
\hline Azerbaijan & $193(68.4)$ \\
\hline \multicolumn{2}{|l|}{ Marital status } \\
\hline Single & $236(83.7)$ \\
\hline Married & $46(16.3)$ \\
\hline \multicolumn{2}{|l|}{ Education level } \\
\hline Primary education & $34(12.0)$ \\
\hline Secondary education & $179(63.5)$ \\
\hline High education & $69(24.5)$ \\
\hline \multicolumn{2}{|l|}{ Income rate } \\
\hline Less than income & $118(41.8)$ \\
\hline Income equal to the expense & $116(41.1)$ \\
\hline More than income & $48(17.1)$ \\
\hline \multicolumn{2}{|l|}{ Health assurance presence } \\
\hline Yes & $224(79.4)$ \\
\hline No & $58(20.6)$ \\
\hline \multicolumn{2}{|l|}{ Family type } \\
\hline Nuclear family & $203(72.0)$ \\
\hline Extended family & $70(24.8)$ \\
\hline Fragmented Family & $9(3.2)$ \\
\hline \multicolumn{2}{|l|}{ Place of residence } \\
\hline Village & $63(22.3)$ \\
\hline District center & $76(27.0)$ \\
\hline City center & $143(50.7)$ \\
\hline \multicolumn{2}{|l|}{ Profession } \\
\hline Officer & $57(20.2)$ \\
\hline Worker & $49(17.4)$ \\
\hline Housewife & $24(8.5)$ \\
\hline Not working & $46(16.3)$ \\
\hline Other & $106(37.6)$ \\
\hline \multicolumn{2}{|l|}{ Level of religious worship } \\
\hline Very low & $23(8.2)$ \\
\hline Low & $26(9.2)$ \\
\hline Middle & $141(50.0)$ \\
\hline High & $74(26.2)$ \\
\hline Very high & $18(6.4)$ \\
\hline \multicolumn{2}{|l|}{ Religious knowledge level } \\
\hline Very low & $6(2.1)$ \\
\hline Low & $15(5.3)$ \\
\hline Middle & $163(57.8)$ \\
\hline High & $87(30.9)$ \\
\hline Very high & $11(3.9)$ \\
\hline \multicolumn{2}{|l|}{ Movement level according to belief } \\
\hline Never & $8(2.8)$ \\
\hline Sometimes & $37(13.1)$ \\
\hline Most of the time & $133(47.2)$ \\
\hline Always & $104(36.9)$ \\
\hline
\end{tabular}

In this study, the median value of the SRHSS was 8.0 in young women. The median value of the SRHSS sub-dimensions in young women; "Accepted stigma" 3.0, "Internalized stigma" 2.0, "Stigma based attitudes" were found as 3.0. Bayrakceken also found a similar result in his study with individuals aged 18-24. ${ }^{[19]}$

SRHSS median score in young women was statistically significantly higher in primary school graduates. Similar results were found in the studies on stigmatization in the literature. ${ }^{[22-24]}$ The modernization of nursing roles has had an impact on nurses' independent decision-making skills. A nurse-led interaction and training initiative can reduce stigma. ${ }^{[25]}$

SRHSS median score was found to be statistically significantly higher in young women with less than income. In the literature, some studies showed that individuals with high-income levels had less negative attitudes, and stigmatizing attitudes were lower. ${ }^{[26,27]}$ In this study, SRHSS scores were found to be statistically significantly higher in young women and those without health insurance. The results suggests that the absence of social security results from low income and this increases stigma.

To our knowledge, there is no similar study in the literature that showed that as the age increases, the negative attitudes based on stigmatization increase, which suggests that the negative norms of the society increase with the advancement of age. Logieet al. stated that health services should be adjusted according to gender and age. ${ }^{[28]}$ Thus, it is crucial to pay attention to the adolescent age group, which is an important group for sexual and reproductive health. The results obtained in this study suggest that there was a positive statistically significant relationship between "Attitudes Based on Stigma" and age in young women.

There was no statistically significant difference between the median score of SRHSS in young women, and performing religious prayers, acting according to religious knowledge level and belief. In the study conducted by Hall et al., no significant difference was found between religious knowledge, behavior and emotional questions. ${ }^{[18]}$ This situation can be interpreted as the stigmatization levels of individuals are not based on religious beliefs, and there are different underlying factors.

This study has some limitations. Only volunteers among women aged 18-24 participated in this study. Individuals who know how to use a computer/phone to fill the online form and individuals who know how to fill the online form were included in this study. In addition, since the data collection process was limited to one month, $1.6 \%$ of the group was reached. 


\section{Table 2. SRHSS scores according to sociodemographic characteristics}

\begin{tabular}{|c|c|c|c|}
\hline & n (\%) & Median [IQR] & $\mathbf{p}$ \\
\hline \multicolumn{4}{|l|}{ Nationality } \\
\hline Turkey & $89(31.6)$ & $8.0[6.0]$ & \multirow[t]{2}{*}{$0.740^{*}$} \\
\hline Azerbaijan & $193(68.4)$ & $8.0[5.0]$ & \\
\hline \multicolumn{4}{|l|}{ Marital status } \\
\hline Single & $236(83.7)$ & $8.0[6.0]$ & \multirow[t]{2}{*}{$0.479^{*}$} \\
\hline Married & $46(16.3)$ & $8.5[5.0]$ & \\
\hline \multicolumn{4}{|l|}{ Education level } \\
\hline Primary education & $34(12.0)$ & $9.5[5.0]$ & \multirow[t]{3}{*}{$0.036+$} \\
\hline Secondary education & $179(63.5)$ & $8.0[5.0]$ & \\
\hline High education & $69(24.5)$ & $5.0[10.0]$ & \\
\hline \multicolumn{4}{|l|}{ Income rate } \\
\hline Less than income & $118(41.8)$ & $8.0[5.0]$ & \multirow[t]{3}{*}{$0.047 \dagger$} \\
\hline Income equal to the expense & $116(41.1)$ & $9.0[5.0]$ & \\
\hline More than income & $48(17.1)$ & $6.0[7.0]$ & \\
\hline \multicolumn{4}{|c|}{ Health /Insurance assurance presence } \\
\hline Yes & $224(79.4)$ & $8.0[6.0]$ & \multirow[t]{2}{*}{$0.033^{*}$} \\
\hline No & $58(20.6)$ & $9.0[5.0]$ & \\
\hline \multicolumn{4}{|l|}{ Family type } \\
\hline Nuclear family & $203(72.0)$ & $9.0[6.0]$ & \multirow[t]{3}{*}{$0.430 \dagger$} \\
\hline Extended family & $70(24.8)$ & $8.0[4.5]$ & \\
\hline Fragmented Family & $9(3.2)$ & $7.0[3.0]$ & \\
\hline \multicolumn{4}{|l|}{ Place of residence } \\
\hline Village & $63(22.3)$ & $8.0[4.0]$ & \multirow[t]{3}{*}{$0.525 t$} \\
\hline District center & $76(27.0)$ & $8.0[5.0]$ & \\
\hline City center & $143(50.7)$ & $8.0[6.0]$ & \\
\hline \multicolumn{4}{|l|}{ Profession } \\
\hline Officer & $57(20.2)$ & $8.0[7.5]$ & \multirow[t]{5}{*}{$0.420+$} \\
\hline Worker & $49(17.4)$ & $8.0[4.5]$ & \\
\hline Housewife & $24(8.5)$ & $7.5[5.2]$ & \\
\hline Not working & $46(16.3)$ & $8.5[5.0]$ & \\
\hline Other & $106(37.6)$ & $9.0[6.0]$ & \\
\hline \multicolumn{4}{|l|}{ Level of religious worship } \\
\hline Very low & $23(8.2)$ & $10.0[3.0]$ & \multirow[t]{5}{*}{$0.457 \dagger$} \\
\hline Low & $26(9.2)$ & $8.0[7.2]$ & \\
\hline Middle & $141(50.0)$ & $8.0[5.0]$ & \\
\hline High & $74(26.2)$ & $8.0[8.0]$ & \\
\hline Very high & $18(6.4)$ & $8.0[6.0]$ & \\
\hline \multicolumn{4}{|l|}{ Religious knowledge level } \\
\hline Very low & $6(2.1)$ & $9.0[4.2]$ & \multirow[t]{5}{*}{$0.638 \dagger$} \\
\hline Low & $15(5.3)$ & $8.0[5.0]$ & \\
\hline Middle & $163(57.8)$ & $8.0[5.0]$ & \\
\hline High & $87(30.9)$ & $8.0[6.0]$ & \\
\hline Very high & $11(3.9)$ & $10.0[6.0]$ & \\
\hline \multicolumn{4}{|l|}{ Movement level according to Belief } \\
\hline Never & $8(2.8)$ & $9.0[8.5]$ & \multirow[t]{4}{*}{$0.978 t$} \\
\hline Sometimes & $37(13.1)$ & $9.0[5.5]$ & \\
\hline Most of the time & $133(47.2)$ & $8.0[6.0]$ & \\
\hline Always & $104(36.9)$ & $8.0[5.0]$ & \\
\hline
\end{tabular}

SRHSS: Sexual and Reproductive Health Stamping Scale

*Mann-Whitney U test, +Kruskal Wallis test. 


\begin{tabular}{lc}
$\begin{array}{l}\text { Table 3. SRHSS total and sub-dimension scores in young } \\
\text { women }\end{array}$ & Median [IQR] \\
\hline & $8.0[6.0]$ \\
\hline Total SRHSS & $3.0[3.0]$ \\
Accepted stamping sub-dimension & $2.0[4.0]$ \\
Internalized stamping sub-dimension & $3.0[3.0]$ \\
Attitudes on stigmatization sub-dimension & \\
\hline SRHSS: Sexual and Reproductive Health Stamping Scale. & \\
\hline
\end{tabular}

Table 4. Relationship between SRHSS total and subdimension scores with age in young women

\begin{tabular}{llc} 
& \multicolumn{2}{c}{ Age (years) } \\
\cline { 2 - 3 } & \multicolumn{1}{c}{$\mathbf{r}$} & $\mathbf{p}$ \\
\hline Total SRHSS & 0.107 & 0.073 \\
Accepted stamping sub-dimension & 0.043 & 0.472 \\
Internalized stamping sub-dimension & 0.039 & 0.517 \\
Attitudes on stigmatization sub-dimension & 0.171 & 0.004
\end{tabular}

SRHSS: Sexual and Reproductive Health Stamping Scale. Spearman Correlation.

\section{CONCLUSION}

It has been determined that the level of stigmatization varies according to the level of education and income, and it is recommended to provide training on stigmatizing sexual and reproductive health for this group.

\section{Disclosures}

Peer-review: Externally peer-reviewed.

Conflict of Interest: None declared.

Ethics Committee Approval: This study was approved by the Agri Ibrahim Cecen University Scientific Research Ethics Committee (Approval date: 05 Mar 2020, Approval number: E.5938). Verbal permission was obtained from individuals who wanted to participate in this research by making the necessary explanations to the individuals included in this research.

Authorship Contributions: Concept - M.S.Y., M.Y.; Design M.S.Y., M.Y.; Supervision - M.S.Y., M.Y.; Materials - G.O.; Data collection \&/or processing - M.S.Y., M.Y.; Analysis and/or interpretation - M.S.Y., M.Y.; Literature search - G.O. Writing - M.S.Y., M.Y.; Critical review -G.O.

\section{REFERENCES}

1. İnanç BY, Bilgin M, Atıcı MK. Gelişim Psikolojisi. 12nd ed. Ankara: Pegem Akademi; 2017. p. 1-277.

2. Koluaçık S, Güneş $G$, Pehlivan E. İnönü Üniversitesi öğrencilerinin üreme sağlığı konularında bilgi düzeyleri ve hizmetten beklentileri. İnönü Üniversitesi Tıp Fakültesi Dergisi 2010;17:7-14.

3. Koçak DY, Duman NB, Topuz Ş, Yılmazel G, Güngör T, Başçı AB. Üreme çağındaki kadınların acil kontrasepsiyon ile ilgili bilgi, tutum ve davranışları. Jinekoloji-Obstetrik ve Neonatoloji Tıp Dergisi 2016;138(3):112-6.

4. Atan ŞÜ, Duran ET, Şen S, Bolsoy N, Sevil Ü. Üniversite öğrencilerinin cinsellik ve aile planlaması yöntemleri konusundaki bilgi, görüş ve uygulamaları. Ege Üniversitesi Hemşirelik Fakülesi Dergisi 2012;28(1):13-25.

5. WHO. Reproductive health. Available at: http://www.who.int/ topics/reproductive_health/en/. Accessed Apr 20, 2020.

6. Tenore JL, Lipsky MS. Preventive services for the adolescent (1320 years). Clinics in Family Practice 2000;2:289-311. [CrossRef]

7. WHO. International Classification of Functioning, Disability and Health (ICF). 2001. Available at: https://www.who.int/ classifications/icf/en/. Accessed Apr 20, 2020.

8. Charlton BM, Hatzenbuehler ML, Jun HJ, Sarda V, Gordon AR, Raifman JR, et al. Structural stigma and sexual orientationrelated reproductive health disparities in a longitudinal cohort study of female adolescents. Journal of adolescence 2019;74,183-7. [CrossRef]

9. Goffman E. Stigma. Notes on the Management of Spoiled Identity. New York: Simon and Shuster; 1963. p. 2-52.

10. Cuca YP, Onono M, Bukusi E, Turan JM. Factors associated with pregnant women's anticipations and experiences of HIV-related stigma in rural Kenya. AIDS Care 2012;24(9):1173-80. [CrossRef]

11. Hatzenbuehler ML, Phelan JC, Link BG. Stigma as a fundamental cause of population health inequalities. Am J Public Health 2013;103(5):813-21. [CrossRef]

12. Link BG, Yang LH, Phelan JC, Collins PY. Measuring mental illness stigma. Schizophr Bull 2004;30(3):511-41. [CrossRef]

13. Atuyambe L, Mirembe F, Johansson A, Kirumira EK, Faxelid E. Experiences of pregnant adolescents--voices from Wakiso district, Uganda. Afr Health Sci 2005;5(4):304-9.

14. Fenton KA. Time for change: rethinking and reframing sexual health in the United States. J Sex Med 2010;7 Suppl 5:250-2.

15. Hall KS, Kusunoki Y, Gatny H, Barber J. Social discrimination, stress, and risk of unintended pregnancy among young women. J Adolesc Health 2015;56(3):330-7. [CrossRef]

16. WHO. HIV/AIDS. Addressing stigma and discrimination. Available at: http://www.who.int/hiv/topics/vct/toolkit/components/service/en/index8.html Accessed Apr 20, 2020.

17. Saewyc EM, Poon CS, Homma Y, Skay CL. Stigma management? The links between enacted stigma and teen pregnancy trends among gay, lesbian, and bisexual students in British Columbia. Can J Hum Sex 2008;17(3):123-39.

18. Hall KS, Manu A, Morhe E, Harris LH, Loll D, Ela E, et al. Development and Validation of a Scale to Measure Adolescent Sexual and Reproductive Health Stigma: Results From Young Women in Ghana. J Sex Res 2018;55(1):60-72. [CrossRef] 
19. Bayrakçeken E. Genç Kadınlarda Cinsel ve Üreme Sağlığı Damgalama Ölçeği Geçerlik ve Güvenirliği. Yüksek lisans tezi. Erzurum: Atatürk Üniversitesi Sağlık Bilimleri Enstitüsü; 2018.

20. Hock RR. Human Sexuality (Paper): Pearson New International Edition. 3rd ed. London: Pearson Education Limited; 2013.

21. Kömürcü N, Demirci N, Yıldız H, Gün Ç. Türkiye'deki hemşirelik dergilerinden cinselliğe bakış: Bir literatür incelemesi. Hemşirelikte Eğitim ve Araştırma Dergisi 2014;11(1):9-17.

22. Lysaker PH, Tsai J, Yanos P, Roe D. Associations of multiple domains of selfesteem with four dimensions of stigma in schizophrenia. Schizophr Res 2008;98(1-3):194-200. [CrossRef]

23. Pinto-Foltz MD, Logsdon MC. Reducing stigma related to mental disorders: initiatives, interventions and recommendations for nursing. Archieves of Psychiatric Nursing 2009 23(1):32-40. [CrossRef]

24. Alonso J, Buron A, Rojas-Farreras S, de Graaf R, Haro JM, de Girolamo $G$, et al. Perceived stigma among individuals with com- mon mental disorders. J Affect Disord 2009;118(1-3):180-6.

25. Yen CF, Chen CC, Lee Y, Tang TC, Yen JY, Ko CH. Self-stigma and its correlates among outpatients with depressive disorders. Psychiatr Serv 2005;56(5):599-601. [CrossRef]

26. Ersoy MA, Özdemir N, Savaş HA. Tıp fakültesi ve hemşirelik öğrencilerinde alkol ve madde kullanımıyla ilgili tutumlar. Bağımlılık Dergisi 2008;9(1):9-13.

27. Çam O, Çuhadar D. Bipolar bozukluğu olan hastalarda işlevsellik düzeyi ve içselleştirilmiş damgalama arasındaki ilişkinin belirlenmesi. Gümüşhane Üniversitesi Sağlık Bilimleri Dergisi 2013;231-46.

28. Logie $\mathrm{CH}$, Okumu M, Mwima SP, Kyambadde P, Hakiza R, Kibathi IP, et al. Exploring associations between adolescent sexual and reproductive health stigma and HIV testing awareness and uptake among urban refugee and displaced youth in Kampala, Uganda. Sex Reprod Health Matters 2019;27(3):86106. [CrossRef] 